\title{
Beyond outcomes: measuring procedural utility
}

\author{
By Bruno S. Frey ${ }^{\star}$ and Alois Stutzer $\dagger$ \\ ${ }^{*}$ Institute for Empirical Research in Economics, University of Zurich \\ $\dagger$ Institute for Empirical Research in Economics, University of Zurich, \\ Bluemlisalpstrasse 10, 8006 Zurich, Switzerland \\ e-mail: bsfrey@iew.unizh.ch, astutzer@iew.unizh.ch
}

\begin{abstract}
People not only obtain utility from actual outcomes but also from the conditions which lead to these outcomes. The paper proposes an economic concept of this notion of procedural utility. Preferences beyond outcome can be manifold. We distinguish procedural utility people get from institutions as such, i.e., from how allocative and redistributive decisions are taken, procedural utility from activities towards which people have an intrinsic attitude and procedural utility from the way being treated in interaction with other people. In an empirical application, it is studied whether people gain procedural utility from participating in the political decision-making process itself, irrespective of the outcome. Utility is measured by individuals' reported subjective well-being. We find that participation rights provide procedural utility in terms of a feeling of self-determination and influence. In contrast, actual participation and use of participation rights does not.
\end{abstract}

JEL classifications: D60, D63, D72, H73, I31

\section{Introduction}

People are likely to obtain utility not only from actual outcomes but also from the conditions leading to these outcomes. This procedural utility is a quite different source of an individual's well-being than the output included in a traditional utility function. Individuals may, for instance, have preferences for participation and autonomy in decision-making at the workplace, in the market as well as in politics. These are preferences going beyond the expected outcome. When people act within institutions, they may experience a higher subjective well-being when they are treated in a way they consider to be just and fair. Procedural utility resulting from activities is obviously important in the labor market. As Scitovsky (1976) argued in his Joyless Economy, intrinsic work enjoyment is a major source of utility. Scitovsky even proposed that '.. the difference between liking and disliking one's work may well be more important than the differences in economic satisfaction 
that the disparities in our income lead to' (p.103). Thus, utility is reaped from the process itself, over and above the outcome generated. ${ }^{1}$

The possibility of process utility has been largely neglected in economics. ${ }^{2}$ In the standard work tool of economists, game theory, payoffs are usually expressed as von Neumann-Morgenstern utilities, which solely refer to outcomes. Moreover, the ordinal revolution in economics has abandoned any hedonic content of utility. However, a better understanding of utility has to go beyond the decision utility considered in traditional utility theory.

This paper intends to contribute to the empirical analysis of outcome and process utility. It addresses the two major questions in the analysis of procedural utility: (i) How can utility be measured? and (ii) how can outcome and process utility be disentangled? We propose reported subjective well-being as a suitable proxy measure of utility. Measures of reported satisfaction with life and happiness have for decades been extensively studied in psychology and have contributed greatly to the understanding of individual well-being (see e.g., Diener et al., 1999, and Kahneman et al., 1999). In recent years, measures of subjective wellbeing have been successfully applied in economic research (for surveys see Oswald, 1997; Frey and Stutzer 2002a,b). In our application, it is shown that the two types of utility can be measured in a particular, but important, context, namely participatory decision-making. We study participation in democratic decision-making, and its effect on utility in the form of satisfaction with life. In order to address the second question, i.e., to distinguish between the two types of utility which result from participation in democratic decision-making, and to measure their relative size, we investigate differences between nationals and foreigners. National citizens are allowed to participate politically, and therefore may enjoy satisfaction from both outcome and process, while foreigners have no political participation rights and therefore do not enjoy procedural utility from this source.

Section 2 of this paper provides a short theoretical discussion of the concept of procedural utility and introduces reported subjective well-being as a proxy measure for utility in economics. Section 3 outlines the empirical application of the framework for the study of procedural utility from participation in democratic decision-making. Section 4 presents the empirical analyses and addresses the contrast between actual participation and participation rights. The last section offers conclusions.

\footnotetext{
${ }^{1}$ Direct benefits generating procedural utility are thus non-instrumental in nature.

${ }^{2}$ Simon $(1976,1978)$ and Sen (1995) argued generally that economic choice models should combine preferences for outcome as well as for processes. But such amalgamation is not easy to undertake. Harsanyi (1993, p.314) states that procedural utility is incompatible with expected utility theory, and Rabin (1993, p.1285), in game theory, believes that procedural utility certainly cannot be analyzed by appropriately transforming the payoffs of a conventional game.
} 


\section{Procedural utility and economic theory}

\subsection{An economic concept of procedural utility}

The focus on tangible outcomes in the aftermath of the positivistic movement in economics contributed a lot to the success of the economic approach to behavior in the social sciences. However, outcomes are not the only source of utility and not the only driving force behind behavior. There is something beyond instrumental outputs as they are captured in a traditional utility function. People can have preferences about how outcomes are generated. These preferences about procedures generate procedural or process utility (for a general discussion see Frey et al., 2004).

The sources of procedural utility are manifold. We propose to classify them into three broad categories.

First, there is the procedural utility people get from institutions as such. People have preferences about how allocative and redistributive decisions are taken. They may, for example, appreciate the market place for the freedom it provides in individual choice and democracy for the equality it provides in political decision-making. Thus, people get utility from living and acting under particular institutions over and above outcomes. ${ }^{3}$

Second, there is the procedural utility people get from (non-interactive) individual behavior, when they have an intrinsic attitude towards the action or choice process they are involved in. A theoretical literature reflects economists' interest in this kind of procedural utility. In particular, it has been useful to model a specific utility for gambling (see Le Menestrel, 2001). Pascal (1670) was well aware of the fact that people derive utility from the mere act of engaging in an activity such as gambling, and so were Marschak (1950), von Neumann and Morgenstern (1944), and Harsanyi (1993). ${ }^{4}$

Third, it may be argued that procedural utility is involved in the interaction between people. On the one hand, people can get satisfaction from acting in a fair way or by being honest with other people, quite independent of the outcome. On the other hand, people evaluate actions towards them not only by their consequences but also by the intentions behind these actions. ${ }^{5}$ An individual is, for example, emotionally affected in a negative way by an action

\footnotetext{
${ }^{3} \mathrm{~A}$ related literature in health economics debates about process values when assessing equality in health policies. For example, Sen (2002) argues that inequalities in health care matter beyond inequalities in health achievement. Women are therefore not to be discriminated in health care although they have ex ante higher life expectancy due to their biological preconditions. For the relevance of process aspects in epidemiological research see, e.g., Marmot and Wilkinson (1999).

${ }^{4}$ There are two strands of literature in empirical economic research that deal with an object very much related to procedural utility of this second type: the first is compensation differentials in wage rates reflecting the nonmonetary benefits of work (e.g., Rosen, 1986, Viscusi, 1993), and the second is process benefits in studies on the use of time (e.g., Juster and Stafford, 1985).

${ }^{5}$ Economic models of behavior that include the underlying motivation of people are for example Falk and Fischbacher (2000) and Rabin (1993).
} 
when he or she attributes the actor with a criminal motive rather than a neutral motive. $^{6}$

Procedures as a source of individual utility cannot easily be integrated in traditional economic theory, even though they are themselves reflected in behavior. This is because the traditional framework excludes non-instrumental concerns in the behavior affecting people's choices. Otherwise, neoclassical economics' fundamental axiom of monotonicity would be violated and the standard expected utility model could not be applied. To give an example of how people's attitudes towards a procedure infringe the very fundaments of the traditional utility model, consider an individual's preference for autonomous decision-making. People may value taking an autonomous decision rather than delegating it, even though they have to expect a worse outcome on average in return. In this case, observing related individual choice behavior and assessing it from a traditional perspective would necessarily lead to an inconsistent representation of individual preferences.

The concept of procedural utility is related to research on (procedural) fairness in economics and in other social sciences. In field, experiment and survey studies, it has been shown that prosocial preferences influence market behavior (e.g., Kahneman et al., 1986; Bewley, 1999; Fehr and Schmidt, 2003). People are for instance willing to bear the costs of taking revenge if they perceive themselves to be treated in an unfair manner. Prosocial preferences can thus facilitate trade and profit maximization, in particular if they help to overcome social dilemmas. In these cases 'fairness payoffs' (Rabin, 1993, p.1294) are to be added to the material payoffs. Perceived fairness can depend strongly on the applied procedures for decision-making. ${ }^{7}$ Procedures are of particular concern when allocation conflicts cannot exclusively be resolved based on outcomes as well as when there is pervasive uncertainty about the outcomes themselves (e.g., Anand, 2001).

In previous research, concerns for procedural fairness or justice have been seen as almost exclusively instrumental, i.e., people have preferences for fair procedures because they expect desirable outcomes (Thibaut and Walker, 1975). However, there are also theories of procedural fairness in which an intrinsic value is attributed to the process itself, in particular when fairness perceptions are closely linked with notions of agency (e.g., Lane, 1988; Lind and Tyler, 1988). Procedures are then evaluated by the relational information that they convey, such as assessments of impartiality, trustworthiness of superiors and authorities, and the extent to which individuals feel they are treated with dignity (e.g., Tyler et al., 1997). This evaluation also has behavioral consequences: In a study about recidivism in cases of

\footnotetext{
${ }^{6}$ Rabin (2002) emphasizes the need for an extended utility concept if these aspects of individual interaction beyond narrow outcome oriented self-interest are to be integrated in welfare analysis: '. . players in games behave systematically differently as a function of previous behavior by other players. This shows that people care not only about outcomes, but also how they arrived at those outcomes. The fact that preferences cannot be defined solely on outcomes can be reconciled with preference theory, but requires an expansion of the notion of what enters the utility function' (p.15).

${ }^{7}$ For an experimental application see Bolton et al. (2000).
} 
domestic violence, Lind and Tyler (1988) find that recidivism rates are lower when accused people are respectfully treated by arresting officers.

Related research is not restricted to perceived (procedural) fairness, but many other intrinsic pleasures of a procedure have been identified, among them the utility gained by facing and meeting challenges, expressing oneself, using one's talents, and reporting experiences over and above any instrumental value they may have. But procedures may also lower utility, for instance by being cognitively taxing, or by forcing one into making a decision (e.g., Lane, 1988). ${ }^{8}$

The idea of procedural utility goes beyond the narrow consequentialism of standard economics and is thus vulnerable to the accusation of being tautological. However, traditional economics is often also applied as a tautology, in the sense that every observed change in behavior is assumed to reflect changes in relative costs or prices. In order to be a fruitful concept that makes testable predictions, it is necessary to specify conditions under which procedural utility either affects behavior or individual well-being. The latter approach is followed here.

\subsection{Measuring utility}

In this paper, utility is measured in terms of reported subjective well-being. Thus, a proxy measure for utility is applied in order to directly study the concept of procedural utility. Indicators of subjective well-being are increasingly studied and applied in economics as a reliable measure of individual utility (e.g., Clark and Oswald, 1994; Di Tella et al., 2001; Easterlin, 1974; Freeman, 1978; Frey and Stutzer, 2000, 2002a; Kahneman et al., 1997; and for surveys Frey and Stutzer, 2002b; Layard, 2005). With the help of a single question or several questions on global self-reports, it is possible to get indications of individuals' evaluation of their life satisfaction or happiness. Behind the score indicated by a person lies a cognitive assessment to what extent their overall quality of life is judged in a favorable way (Veenhoven, 1993).

Subjective well-being is generally assessed in large-scale surveys. In a number of studies, the validity of these survey measures has been documented. It has, for example, been shown that different measures of happiness correlate well with one another (e.g., Fordyce, 1988). Reliability studies have found that reported subjective well-being is moderately stable and sensitive to changing life circumstances (e.g., Ehrhardt et al., 2000; Headey and Wearing, 1991). Consistency tests reveal that happy people are more often smiling during social interactions (Fernández-Dols and Ruiz-Belda, 1995), are rated as happy by friends and family members (Sandvik et al., 1993), as well as by spouses (Costa and McCrae, 1988), are less likely to

\footnotetext{
${ }^{8}$ A psychological underpinning of procedural utility is provided by several theories in psychology. In self-determination theory, participation and autonomy in decision-making provide procedural goods that serve innate needs of competence, autonomy and relatedness and thus contribute to individual wellbeing (Deci and Ryan, 2000). In the group-value model of Lind and Tyler (1988), procedural justice is seen to build group solidarity and to strengthen its members' good standing in a group. Procedural utility is thus provided by fulfilling individuals' long-term affiliated needs.
} 
commit suicide (Koivumaa et al., 2001) and that changes in brain electrical activity and heart rate account for substantial variance in reported negative affect (Davidson et al., 2000). The existing state of research suggests that, for many reasons, reported subjective well-being is a satisfactory empirical approximation to individual utility. It is thus possible to study procedural effects on individual well-being directly.

\section{Application: procedural utility from participation}

A large literature in the social sciences, especially in psychology, political science, and sociology, attributes a positive value to participation, as it enhances individuals' perception of self-determination (for an extensive survey see Lane, 2000, ch.13). Participation is thereby considered as an activity, as well as a characteristic of an institution. People can have preferences about both of these procedural aspects of participation, which go beyond the outcome of a participatory decision-making mechanism. In the following analysis, we focus on procedural utility from participation as a characteristic of a state of being, i.e., living and acting under democratic institutions that grant participation rights. In the robustness analysis, we also take procedural utility from the activity, i.e., actual participation, into consideration.

The right to participate in political decisions is a crucial characteristic of any democratic institution. People can gain procedural utility from this state of being as they may have preferences about the democratic institutions within which they live, and act beyond the outcome that is generated by democratic decision-making. They may feel that the political sphere takes their wishes seriously into account in a fair political process, or they may feel alienation and apathy towards the political institutions installed. Moreover, they may have a firm or weak belief that the democratic process is responsive to them, independent of the goods and services they are provided with by the state. ${ }^{9}$ Participation rights in the political mechanism of decision-making, ranging from voting in elections, launching and voting on referenda, to running for a seat in parliament, may thus provide a feeling of being involved and having political influence, as well as a notion of inclusion, identity and self-determination. It may even be hypothesized that the right to participate in political decision-making accords the citizens more encompassing self-determination than actual participation, because political participation rights are a comprehensive characteristic of political institutions and affect people's wellbeing, and not only during a restricted period of political activation. With the rights to participate, the decision is left up to the individual of whether to actually participate or not. Persons may value the right to participate even if they rarely or never exercise it themselves.

\footnotetext{
${ }^{9}$ A different view is proposed in the literature on voice in procedural justice. In the early work of Thibaut and Walker (1975), it is argued that people want the right to participate so that they can influence the outcome of a process. This work argues for a purely instrumental model of participation. The preference for participation is thus restricted to its option value.
} 
In most countries, the status of being a national fundamentally differs from that of being a foreigner, by providing the right to vote and to participate in political decision-making in general. In many other ways, the law demands that they are treated equally. Thus, for example, they have the same human rights and, once admitted into the country, they have (with few exceptions) the same rights to participate in economic affairs. It cannot, of course, be denied that the national legislation and political decisions tend to be in favor of nationals. However, it follows that, on average, the nationals derive more utility from political participation rights than foreigners do, provided that nationals enjoy both outcome and process utility, while the foreigners only enjoy outcome utility.

The distinction between nationals and foreigners is largely exogenous. Whether a person may become a citizen or not is determined by law, in particular the requirement of having stayed in the host country for a sufficient number of years, having sufficient mastery of the local language and the content of the constitution. Only after these stringent requirements are met, does an individual have the choice of becoming a citizen. Of course, whether those persons eligible for citizenship indeed accept it, also depends inter alia on their expected procedural utility, i.e., their wish to become a community member with full participation rights. Some will decide not to change their citizenship. Becoming a citizen is more or less automatic for young persons and spouses, once the head of the household has decided to do so. In contrast, resident citizens have no possibility of choosing their status of citizenship. They cannot give up their current citizenship without relocation. The distribution of residents in a country between the two categories, foreigners and citizens, thus strongly reflects formal exogenous criteria for citizenship, and not revealed preferences for procedural goods. As a result of these considerations, one may assume that the distinction between nationals and foreigners influences the extent to which one benefits from outcome and process utility, while the reverse causation can be ignored. We also assume that differences in outcome discrimination of foreigners at the sub-federal level can be neglected. This is a necessary restriction in order to identify the existence and relative importance of procedural utility. It also shows the limits of our strategy. ${ }^{10}$

On the basis of our discussion, the following empirically testable hypothesis can be formulated:

The utility derived from the right to participate in the political process (measured by the extent of direct democratic rights across regions) supports the subjective well-being of the citizens. The foreigners living in the same region, who

\footnotetext{
${ }^{10} \mathrm{We}$ think that the assumption of non-systematic discrimination of foreigners at the sub-federal level can be defended. First, in Switzerland, the economic restrictions and rights of foreigners are almost exclusively dealt with at the national level (like the restricted access to some professions). Second, previous research for Switzerland does not find evidence for a serious problem of a 'tyranny of the majority'. While Gamble (1997) finds some evidence for the suppression of civil rights in local and state ballots in the United States, there is evidence to the contrary for the USA and Switzerland (Cronin, 1989; Frey and Goette, 1998).
} 
are excluded from this process, experience lower levels of happiness than the citizens.

In this hypothesis, the strategy used to identify procedural utility is based on the formal distinction between citizens and foreigners. The corresponding statistical approach is in analogy to the differences-in-differences estimator for time series. In a crude formulation, procedural utility is the additional positive effect of more extended participation rights for citizens' well-being compared to that for foreigners'.

\section{Empirical analysis}

\subsection{Data and descriptive analysis}

We study the proposed hypothesis using a survey based on more than 6,000 interviews with residents of Switzerland, collected by Leu et al. (1997). ${ }^{11}$ The proxy measure for individual utility is based on the answers to the following question: 'How satisfied are you with your life as a whole these days?' Simultaneously, the respondents were shown a table with a 10-point scale, of which only the two extreme values ('completely dissatisfied' and 'completely satisfied') were verbalized. The survey found a high general life satisfaction in Switzerland, with an average of 8.2 out of 10 points. While this is a high score, there are also other Western countries, in particular in Scandinavia, with similar levels of life satisfaction.

Data for Switzerland is studied because of unique variation in political participation rights. In Switzerland, in addition to elections, there are several different ways of engaging directly in the political process at three state levels. Most important are the direct democratic instruments. They exist at a national level, as well as at the level of the 26 cantons (states). The cantonal level is considered here, because participation rights at the national level apply equally across the country. In cantons, the major direct democratic instruments are the popular initiatives to change the canton's constitution or laws, a compulsory and optional referendum to prevent new laws, or the changing of existing laws, and an optional financial referendum to prevent new state expenditure. Due to the federal structure of Switzerland, major areas of competence are held by the cantons and, thus, there is a high potential influence of direct legislation on the outcome of the political process in Swiss cantons. However, citizens' access to these instruments differs substantially from canton to canton. Thus, for example, the number of signatures required to launch an initiative or an optional referendum, or the time span within which the signatures have to be collected, varies. The referendum on public expenditures may be launched at different levels of additional outlays. We constructed an index designed to reflect the extent of direct democratic participation rights in the

\footnotetext{
${ }^{11}$ The survey data were collected between 1992 and 1994 in order to investigate the problem of poverty in Switzerland. The information contained in the data set is based on personal interviews and tax statistics.
} 
Table 1 Satisfaction with life and participation rights, descriptive statistics

\begin{tabular}{lccc}
\hline & \multicolumn{2}{c}{ Participation rights } & \\
& Weak & Strong & Difference \\
\hline Whole sample & 8.099 & 8.318 & $0.218^{* *}$ \\
& $(0.033)$ & $(0.029)$ & $(0.044)$ \\
Foreigners & 7.625 & 7.602 & -0.023 \\
& $(0.090)$ & $(0.104)$ & $(0.136)$ \\
Swiss citizens & 8.176 & 8.402 & $0.226^{\star *}$ \\
& $(0.036)$ & $(0.029)$ & $(0.046)$ \\
Difference & $0.551^{* *}$ & $0.800^{* *}$ & $0.249^{*}$ \\
(Swiss citizens-foreigners) & $(0.096)$ & $(0.092)$ & $(0.133)$ \\
\hline
\end{tabular}

Notes: Standard errors in parentheses. Significance levels: ${ }^{\star} 0.05<p<0.10,{ }^{* *} p<0.05$.

Data sources: Leu et al. (1997) and Stutzer (1999).

26 cantons (for details of the index construction, see the Appendix). This index is defined using a six point scale, with one indicating the lowest, and six the highest degree of participation rights for the citizens.

According to the hypothesis formulated above, more developed participation rights are expected to increase reported satisfaction with life, due to a larger increase in procedural utility. In Table 1 , the utility difference between residents living in cantons with weak participation rights (the index is lower than four) and with strong participation rights is reported. ${ }^{12}$ On average, residents with strong participation rights report a 0.22 point higher level of well-being. However, this difference may also be due to a favorable outcome of the political process. There is ample evidence that in more direct democratic jurisdictions the outcome of the political process is closer to the wishes of the residents (see e.g., Frey, 1994; and the survey by Kirchgässner et al., 1999). In order to differentiate between outcome and procedural utility, the proposed identification criteria of people's nationality is considered. ${ }^{13}$ As foreigners are excluded from political participation rights, but not from the outcome of the political process, differences in levels of satisfaction between citizens and foreigners in cantons with weak and strong participation rights have to be compared. Where participation rights are weak, a difference in well-being between Swiss citizens and foreigners of 0.55 points is measured. The respective difference in cantons with extended direct democratic rights is 0.80 points. Both gaps in subjective well-being are due to differences in individual characteristics, incomplete assimilation and, above all, the citizens' opportunity to reap procedural utility. The differences-in-differences between cantons with weak and strong participation rights then reflects the gain in procedural utility of citizens due to more extended participation rights. The raw data show a large

\footnotetext{
${ }^{12}$ A cut-off point of four is selected in order to split the sample into two sub-samples with an approximately equal number of individual observations.

${ }^{13}$ The percentage of foreigners in the population for Switzerland was 18.5 percent between 1992 and 1994.
} 
effect of procedural utility in terms of reported satisfaction with life of 0.25 points. ${ }^{14}$ A multiple regression analysis has to test whether this result still holds if individual characteristics are controlled for. An ordered probit estimation and extended discussion of the result is provided in the next subsection.

\subsection{Results of the econometric analysis}

The descriptive analysis presented above offers preliminary evidence for positive procedural utility caused by stronger participation rights. A multiple regression analysis has to show whether this result is robust. Once again, a differences-indifferences estimation strategy is applied to identify procedural utility. Technically, an interaction term is included in the estimation equation that combines the variable that captures the proposed source of procedural utility with the identifying criteria. Here, the identifying characteristic is being a foreigner.

Table 2 presents the estimated coefficients and marginal effects of a microeconometric happiness function, taking into account participation rights, as well as a large set of control variables. In order to exploit the ranking information contained in the originally scaled dependent variable, a weighted ordered probit model is applied. ${ }^{15}$ The weighting variable used allows representative results at an individual level for Switzerland. ${ }^{16}$ Throughout the remainder of the paper, we use a robust

\footnotetext{
${ }^{14}$ An alternative differences-in-differences interpretation considers the rows in Table 1 instead of the columns. Given that foreigners cannot reap procedural utility from the democratic process because they are formally excluded, the difference in reported life satisfaction between people living in cantons with weak and with strong participation rights is due to a difference in outcome utility. For the raw data, the difference in outcome utility is close to zero. In the case of Swiss citizens, the difference includes procedural as well as outcome utility. The raw effect of stronger participation rights is on average 0.2 points on the satisfaction scale. Considering both foreigners and Swiss citizens, the differences-indifferences due to procedural utility is 0.2 points.

${ }^{15}$ The use of ordered probit or logit to estimate microeconometric happiness functions is based on the following intuition: Person $i$ experiences in time period $t$ true well-being or utility $W_{i t}^{*}$. $W_{i t}^{*}$ is the latent variable that depends on a set of institutional, socio-demographic and personal characteristics $x_{i t}$ and some independent random errors $\varepsilon_{i t}$ :
}

$$
W_{i t}^{*}=x_{i t} \beta+\varepsilon_{i t} .
$$

People do not report latent well-being $W^{*}$ but can only give a discrete value on, e.g., a scale from 1 to 10. Reported well-being $W_{i t}$ takes score $k$ with $1 \leq k<10$ whenever $W_{i t}^{*}$ is between two thresholds $\lambda_{k-1}$ and $\lambda_{k}$ :

$$
W_{i t}=k \Longleftrightarrow \lambda_{k-1}<W_{i t}^{*} \leq \lambda_{k}
$$

Zavoina and McKelvey (1975) developed a procedure (called ordered probit) that chooses estimates for $\beta$ (i.e., the relation between observed characteristics and well-being), as well as for the thresholds $\lambda_{k}$ so that the estimated probability of the observed responses is maximised. Mathematically, $\beta$ is chosen so that $\Sigma \ln \left(p_{k}\right)$ is maximised with the probability $p$ of observing level $k: p_{k}=P\left(\lambda_{k-1}<x_{i t} \beta+\varepsilon_{i t} \leq \lambda_{k}\right)$.

${ }^{16}$ Due to clustering and stratification, in contrast to pure random sampling, weights are necessary to get approximately unbiased point estimates. Weights are proportional to the inverse of the probability of being sampled. In addition, the weights are adjusted to the demographic structure in 1992. 
Table 2 Procedural utility and participation rights.

Dependent variable: satisfaction with life

\begin{tabular}{|c|c|c|c|}
\hline & \multicolumn{3}{|c|}{$\begin{array}{l}\text { Weighted ordered probit } \\
\text { Std. err. adjusted to clustering on } 26 \text { cantons }\end{array}$} \\
\hline & Coefficient & $t$-value & Marginal effect (score 10) \\
\hline Participation rights (PR) & 0.097 & 3.22 & 0.033 \\
\hline PR x foreigner (ITPR) & -0.067 & -1.75 & -0.023 \\
\hline Foreigner & -0.042 & -0.29 & -0.014 \\
\hline \multicolumn{4}{|l|}{ Demographic variables } \\
\hline Age $30-39$ & -0.089 & -1.00 & -0.030 \\
\hline Age $40-49$ & -0.013 & -0.17 & -0.004 \\
\hline Age $50-59$ & -0.009 & -0.15 & -0.003 \\
\hline Age $60-69$ & 0.302 & 4.24 & 0.108 \\
\hline Age $70-79$ & 0.378 & 4.51 & 0.137 \\
\hline Age 80 and older & 0.355 & 3.07 & 0.130 \\
\hline Female & 0.033 & 1.02 & 0.011 \\
\hline Bad health & -0.434 & -7.63 & -0.132 \\
\hline Middle education & 0.077 & 2.22 & 0.026 \\
\hline High education & 0.039 & 0.88 & 0.013 \\
\hline Separated, without partner & -0.590 & -2.30 & -0.162 \\
\hline Separated with partner & -0.664 & -1.82 & -0.177 \\
\hline Widowed, without partner & -0.204 & -4.02 & -0.066 \\
\hline Widowed with partner & 0.078 & 0.51 & 0.027 \\
\hline Divorced, without partner & -0.348 & -4.14 & -0.106 \\
\hline Divorced with partner & -0.094 & -0.74 & -0.031 \\
\hline Single, without partner & -0.175 & -2.55 & -0.057 \\
\hline Single with partner & -0.085 & -1.37 & -0.028 \\
\hline \multicolumn{4}{|l|}{ Socio-economic variables } \\
\hline Self-employed & 0.056 & 1.06 & 0.019 \\
\hline Unemployed & -0.780 & -4.56 & -0.200 \\
\hline Student & -0.022 & -0.24 & -0.008 \\
\hline Housewife & 0.119 & 2.09 & 0.042 \\
\hline Retired & -0.157 & -2.58 & -0.053 \\
\hline Other employment status & 0.082 & 0.60 & 0.029 \\
\hline \multicolumn{4}{|l|}{ Equivalence income } \\
\hline SFr. $2000-3000$ & 0.065 & 1.86 & 0.022 \\
\hline SFr. $3000-4000$ & 0.121 & 2.66 & 0.042 \\
\hline SFr. $4000-5000$ & 0.259 & 4.67 & 0.093 \\
\hline SFr. 5000 and more & 0.184 & 3.54 & 0.065 \\
\hline \multicolumn{4}{|l|}{ Contextual variables } \\
\hline Member in associations & 0.167 & 6.98 & 0.056 \\
\hline Urbanization & -0.057 & -1.34 & -0.020 \\
\hline French speaking canton & -0.075 & -0.96 & -0.025 \\
\hline Italian speaking canton & 0.297 & 4.30 & 0.108 \\
\hline Observations & 6124 & & \\
\hline Prob $>F$ & 0.0002 & & \\
\hline
\end{tabular}

Notes: Dependent variable: level of satisfaction on a ten point scale. White estimator for variance. Reference group: 'Swiss', 'people younger than 30', 'men', 'healthy people', 'people with low education', 'couples', 'employed people', 'people with a lower equivalence income than Sfr. 2,000', 'people who have no membership in associations', 'people living in non-urban areas', and 'German speaking canton'. Data source: Leu et al. (1997). 
estimator of variance, because random disturbances are potentially correlated within groups or clusters. Here, dependence refers to residents of the same canton. ${ }^{17}$

The estimation results show sizeable effects for both variables considered in the basic hypothesis (they are shown at the top of Table 2). The overall effect of participation rights (PR) on reported satisfaction with life is positive. In the ordered probit estimation, a positive coefficient indicates that the probability of stating well-being greater than any given level increases. The positive effect can be attributed to a gain in outcome or procedural utility in cantons with more extended participation rights. The interaction term ITPR in the second row reveals the difference in positive effects for Swiss citizens and foreigners. The negative coefficient indicates that foreigners benefit less from stronger participation rights than the people in the reference group, i.e., the citizens. This result is consistent with the hypothesis that foreigners gain less procedural utility from direct democratic participation rights than Swiss nationals. It has to be noted that the difference in the average subjective well-being of foreigners and citizens is captured in a separate control variable, which is not interpreted in terms of procedural utility.

If it is assumed that foreigners do not reap any procedural utility at all, but cannot be excluded from the outcome of the political process, the relative size of procedural utility can be assessed. Comparing the negative coefficient of the interaction variable, which captures procedural utility under these assumptions, with the coefficient for the variable participation rights, suggests that two thirds of the positive effect of more extended direct democratic participation rights are due to procedural utility and one third stems from outcome utility.

An absolute interpretation of the size of the effects is provided by the marginal effect. The marginal effect indicates the change in the proportion of persons belonging to a stated satisfaction level when the independent variable increases by one unit. ${ }^{18}$ In the case of dummy variables, the marginal effect is evaluated with regard to the reference group. It must hold that if changes over all categories are summed up they add up to zero. In order to measure the shift in the distribution, we therefore only show the marginal effects for the top class of complete satisfaction with life (score 10) in Table 2. An increase in the index of participation rights by one point raises the proportion of persons indicating very high satisfaction with life by 3.3 percentage points. For foreigners, however, this effect is smaller, as the interaction term ITPR has to be considered. 2.3 percentage points of the increased probability of reporting maximum subjective well-being cannot be reaped by the foreigners. Based on the assumptions made, this is because they are excluded from the political process and thus from procedural utility.

\footnotetext{
${ }^{17}$ Ignoring the clustering in the estimation model is likely to produce downward biased standard errors, due to the effects of aggregate variables on individual data (Moulton, 1990). To get unbiased standard errors for the aggregate variable 'participation rights', the 26 cantons are used as sample units.

${ }^{18}$ Alternatively, the marginal effect indicates the change of probability belonging to a stated satisfaction level when the independent variable increases by one unit.
} 
The effect of procedural utility, as reflected in reported life satisfaction itself, is sizeable. This can be seen when the total variation in participation rights is considered, i.e., when citizens in canton Basel Land (with the highest democracy index of 5.69) are compared to citizens in canton Geneva (with the lowest direct participation rights of 1.75). The former benefit from procedural utility, which increases their probability of being completely satisfied by approximately 9.1 percentage points $([5.69-1.75] \times 2.3$ percentage points $)$. This effect for procedural utility is larger than the effect of being in the top income category ( $>$ Sfr. 5,000 per month) rather than in the bottom income category ( $<$ Sfr. 2,000 per month), which is the reference category in Table 2. The latter effect amounts to 6.5 percentage points.

The results discussed so far hold ceteris paribus, i.e., if a number of determinants or correlates of happiness are controlled for. Most important are individual sociodemographic characteristics. In the estimation equation, the respondent's age, gender, health status, educational level, civil status, employment status, and household income are considered. The results for these variables are discussed in Frey and Stutzer (2000) and are similar in size and direction to those found in other microeconomic happiness functions (see, e.g., Blanchflower and Oswald, 2004). In addition, four variables are included that control for three potential alternative explanations. Firstly, a dummy variable for people's participation in clubs or associations is used to test whether citizens in cantons with stronger participation rights may have accumulated more Putnam (2000) style social capital and thus enjoy higher subjective well-being than citizens in cantons with less extended democratic rights. Secondly, a dummy variable for living in an urban area is included to investigate the argument that direct democratic rights could be weaker in urban areas where most of the foreigners live, and thus the raw effect may reflect urbanization. Thirdly, dummies for the language that is spoken in the canton are included in order to test whether the patterns in the descriptive statistics may capture cultural differences within Switzerland instead of institutional variation. However, as presented in Table 2, even controlling for these factors, participation rights have a sizeable effect on individual procedural utility.

\subsection{Robustness analysis: participation rights versus actual participation}

Participation in democracy can be characterized by rights but it is also reflected in actual participation. Actual participation is thus another aspect of participatory political decision-making, which may provide procedural utility. The standard calculus of voting based on expected utility maximization solely considers outcome utility (see Mueller, 1989; Aldrich, 1997). It concludes that rational voters never participate in political decisions, because the probability of affecting the outcome is close to zero with most sizes of electorates, while there are participation costs. However, this prediction is at odds with the empirical observations that citizens do indeed cast their votes, even if their expected influence is virtually nil. This throws doubt on the rational choice approach as traditionally formulated. Some authors therefore have identified various procedural utilities which voters may derive from 
political participation, for instance a utility from compliance with their sense of civic duty or from the value of expressing an ideological view (Hardin, 1982; Brennan and Buchanan, 1985; Jones and Hudson, 2000; Schuessler, 2000).

To check the reliability of the previous results, two robustness tests are performed that include indicators of actual participation. The first indicator of actual participation is voting participation in national ballots. National ballots are considered in order to keep the content of the ballots equal for all the voters. This does not mean that the expected outcome utility of the voting decision is equally distributed across jurisdictions. Consequently, we again use a differencesin-differences approach to conduct the empirical analysis. The participation rate is measured at the cantonal level. Average actual participation is calculated for 45 national ballots on referenda and initiatives. These ballots were held between February 19, 1992 and December 4, 1994, i.e., during the same years that the personal interviews were conducted. An overview of the variation in actual participation rates across cantons is presented in the Appendix.

Table 3 shows the results for two ordered probit estimations that include voting participation. In panel A the average participation rate (PRATE) and the interaction variable with citizen status (ITPRATE) are included without and in panel B with the variable for participation rights. The variable for the actual participation rate tests for a partial correlation between actual participation and reported satisfaction with life. The statistically insignificant coefficients suggest that there is no such relationship in the data set at hand. Whether this negligible correlation is due to a net effect that equalizes a positive effect due to procedural utility, and a negative effect caused by low outcome utility in cantons with high participation rates, is tested with the interaction variable ITPRATE. ITPRATE identifies the contribution of active participation on subjective well-being that is independent of any outcome considerations. However, the coefficients of the interaction term in panel A and B are also estimated very imprecisely and give no evidence of a correlation between life satisfaction and actual participation. ${ }^{19}$ This result, however, does not imply that the exercise of voting rights yields no utility. It might simply be the case that there is heterogeneity across voters in their benefits from voting. If they optimize and self-select as voters and non-voters, we need not expect to see any difference in utilities across people with different likelihoods to vote. In contrast, if procedural utility from voting provides extra pleasure utility differentials would be possible. ${ }^{20}$

\footnotetext{
${ }^{19}$ The estimation results for a sample excluding observations from canton Schaffhausen-the only canton with compulsory voting — neither differ qualitatively nor quantitatively from the ones reported in the text.

${ }^{20}$ In order to make this claim testable, one would need a theory about the relation between the nature of preferences and people's well-being. A proper test would, moreover, require a strategy to identify exogenous variation in actual participation. Laws on compulsory voting, as suggested by one referee, are one possible instrument. However, in the Swiss context there is only one canton left, Schaffhausen, applying such a rule. More variation would be needed for an empirical test.
} 
Table 3 Procedural utility and actual participation. Dependent variable: satisfaction with life

\begin{tabular}{|c|c|c|c|c|}
\hline & \multicolumn{4}{|c|}{$\begin{array}{l}\text { Weighted ordered probit } \\
\text { Std. err. adjusted to clustering on } 26 \text { cantons }\end{array}$} \\
\hline & A & B & $\mathrm{C}$ & $\mathrm{D}$ \\
\hline Participation rights (PR) & & $\begin{array}{c}0.104 \\
(3.57)\end{array}$ & & $\begin{array}{c}0.106 \\
(3.33)\end{array}$ \\
\hline PR $x$ foreigner (ITPR) & & $\begin{array}{l}-0.090 \\
(-2.37)\end{array}$ & & $\begin{array}{l}-0.080 \\
(-2.00)\end{array}$ \\
\hline $\begin{array}{l}\text { Actual participation rate/ } 10 \\
\text { (PRATE) }\end{array}$ & $\begin{array}{r}0.013 \\
(0.16)\end{array}$ & $\begin{array}{l}-0.048 \\
(-0.78)\end{array}$ & & \\
\hline PRATE $\mathrm{x}$ foreigner (ITPRATE) & $\begin{array}{l}-0.030 \\
(-0.34)\end{array}$ & $\begin{array}{c}0.086 \\
(1.16)\end{array}$ & & \\
\hline $\begin{array}{l}\text { Use of participation instruments } \\
\text { (USEP) }\end{array}$ & & & $\begin{array}{l}-0.002 \\
(-0.79)\end{array}$ & $\begin{array}{l}-0.004 \\
(-2.03)\end{array}$ \\
\hline USEP $\mathrm{x}$ foreigner (ITUSEP) & & & $\begin{array}{l}-0.001 \\
(-0.31)\end{array}$ & $\begin{array}{c}0.002 \\
(0.41)\end{array}$ \\
\hline Foreigner & $\begin{array}{l}-0.144 \\
(-0.34)\end{array}$ & $\begin{array}{l}-0.367 \\
(-1.08)\end{array}$ & $\begin{array}{l}-0.261 \\
(-2.50)\end{array}$ & $\begin{array}{r}-0.033 \\
(1.02)\end{array}$ \\
\hline $\begin{array}{l}\text { Demographic variables } \\
\text { Socio-economic variables } \\
\text { Contextual variables }\end{array}$ & & 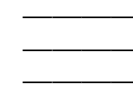 & $\bar{\square}$ & \\
\hline Observations & 6124 & 6124 & 6124 & 6124 \\
\hline Prob $>F$ & 0.0000 & 0.0000 & 0.0002 & 0.0002 \\
\hline
\end{tabular}

Notes: Dependent variable: level of satisfaction on a ten point scale. White estimator for variance. T-values in parentheses. Reference group: 'Swiss', 'people younger than 30', 'men', 'healthy people', 'people with low education', 'couples', 'employed people', 'people with a lower equivalence income than Sfr. 2,000', 'people who have no membership in associations', 'people living in non-urban areas', and 'German speaking canton'.

Data sources: Année politique Suisse (1993-95), Leu et al. (1997) and Swiss Federal Statistical Office (1993-95).

While there is no procedural utility of actual participation reflected in reported subjective well-being, the effect for participation rights seems robust. The overall effect for democratic participation rights as well as the interaction effect that captures procedural utility are of similar size as in Table 2 and are estimated with a low standard error.

The second sensitivity test focuses on the use of participation instruments. It is studied whether citizens get procedural utility from the democratic rights themselves or rather from their application in the political process. ${ }^{21}$ Direct democratic decision-making at lower levels of the state is often seen as a social event serving

\footnotetext{
${ }^{21}$ With this second test, we also address the contrast between the existence of formal norms (rules-inform) and the application of norms (rules-in-use) (Sproule-Jones 1993). It is often argued that institutional analysis should focus on rules-in-use to study policy outcomes. However, direct participation rights reflect not only de jure institutions but capture de facto possibilities of the citizens to intervene in the political process. The results in Table 3 indicate that the degree of formal participation rights is a better indicator of citizens' influence in the political process than the use of these rights.
} 
needs for social relatedness. This would be quite a different source of procedural utility than discussed with regard to participation rights.

Panel C and D in Table 3 present two happiness equations that include indicators for the use of political participation instruments (USEP). In order to discriminate between outcome utility and any sort of process utility interaction terms are added (ITPR, ITUSEP). The use of democratic instruments is measured by the number of ballots that have been conducted in the years between 1992 and 1994 in Swiss cantons. An overview of the variation in the use of direct democratic instruments is presented in the Appendix. The results in panel $\mathrm{C}$ give no indication for a direct relation between the use of instruments of direct political participation and the reported level of satisfaction with life and do not allow the identification of any sort of procedural utility. The size of the coefficients is not trivial but they are measured with very low statistical precision. Panel D provides a clearer picture. It shows that the differentiated effects of participation rights on citizens' and foreigners' subjective well-being is robust to the inclusion of a second indicator of actual participation. Moreover, the actual use of participation rights seems negatively correlated with reported satisfaction with life. As there is only a weak differentiated effect for foreigners, this might indicate that the number of ballots for a given level of participation possibilities captures the degree of antagonism within a particular society.

Overall, it may be argued that actual participation, which affects people's wellbeing only during a restricted period of political activation, is less comprehensive than political participation rights. This is reflected in the supportive evidence for procedural utility from participation rights while there are no clear indications for differentiated effects of actual participation on citizens' and foreigners' subjective well-being.

\section{Conclusions}

The concept of procedural utility represents a different approach to human wellbeing from the standard outcome-oriented approach in social science research. Procedural utility refers to the utility that people gain from the decision-making process itself, irrespective of the outcome.

In this paper, participatory decision-making in politics is considered a possible source of procedural utility. People may have a preference for participation as an activity as well as a characteristic of an institution. ${ }^{22}$ If so, the right to directly participate in the democratic process gives citizens a sense that their preferences are seriously taken into account in a fair political process. Foreigners who are excluded

\footnotetext{
${ }^{22}$ In our analysis, we discuss procedural utility for given preferences and are thus orthodox in this dimension. Future research might consider that processes change values (i.e., preferences) and therewith change utility indirectly. This has been argued in particular for the role of discussion in the democratic process (Buchanan, 1954; and Frey, 1994).
} 
from political decision-making cannot gain such procedural utility. The results of our empirical analysis are consistent with this notion of procedural utility. Citizens, as well as foreigners, living in jurisdictions with more developed political participation rights, enjoy higher levels of subjective well-being. The positive effect on reported satisfaction with life is, however, smaller for foreigners, reflecting their exclusion from procedural utility. It is thus empirically feasible to distinguish between outcome and process utility. It is also possible to get a notion of the relative size of outcome and process utility. The positive effect of participation rights is three times as large for the citizens as it is for the foreigners, i.e., a major part of the welfare gain from the favorable political process is due to procedural utility. Moreover, if the full range of participation rights is considered, procedural utility accounts for larger differences in subjective well-being than the full range of individual income.

Actual political participation is often rationalized by individuals' experience of procedural utility. Here it is argued that participation rights are more important in terms of a feeling of control, self-determination or influence on the political sphere than actual participation is. This hypothesis is not rejected, as we neither find statistically significant nor sizeable positive effects of high participation rates and frequent use of participation instruments on individual well-being.

Overall, 'going beyond outcomes' helps us to better understand what individuals value. We submit that individuals value both outcomes and procedures and, in particular, that they derive substantial utility from political participation rights.

\section{Acknowledgements}

We wish to thank Matthias Benz, Robert Cooter, Rafael Di Tella, Lorenz Götte, Reto Jegen, Robert Lane, Marc Le Menestrel, Robert MacCulloch, Felix Oberholzer-Gee and Tom Tyler for their helpful comments.

\section{References}

Aldrich, J.H. (1997) When is it rational to vote?, in D.C. Mueller (ed.) Perspectives on Public Choice. A Handbook, Cambridge University Press, Cambridge, 373-90.

Anand, P. (2001) Procedural fairness in economic and social choice: evidence from a survey of voters, Journal of Economic Psychology, 22, 247-70.

Année politique Suisse (1993-1995) Chronik zur schweizerischen Politik, Institut für Politikwissenschaft, Bern.

Blanchflower, D.G. and. Oswald, A.J. (2004) Well-being over time in Britain and the USA, Journal of Public Economics, 88, 1356-86.

Bewley, T.E. (1999) Why Wages Don't Fall During a Recession. Harvard University Press, Cambridge and London.

Bolton, G.E., Brandts, J., and Ockenfels, A. (2000) Fair procedures. Evidence from games involving lotteries, mimeo, Department of Economics, Penn State University, Philadelphia. 
Brennan, G. and Buchanan, J.M. (1985) The Reason of Rules. Constitutional Political Economy, Cambridge University Press, Cambridge.

Buchanan, J.M. (1954) Social choice, democracy, and free markets, Journal of Political Economy, 62, 114-23.

Clark, A.E. and Oswald, A.J. (1994) Unhappiness and unemployment, Economic Journal, 104, 648-59.

Costa, P.T. and McCrae, R.R. (1988) Personality in adulthood: a six-year longitudinal study of self-reports and spouse ratings on the NEO personality inventory, Journal of Personality and Social Psychology, 54, 853-63.

Cronin, T.E. (1989) Direct Democracy. The Politics of Initiative, Referendum and Recall, Harvard University Press, Cambridge, MA.

Davidson, R.J., Marshall, J.R., Tomarken, A.J., and Henriques, J.B. (2000) While a phobic waits: regional brain electrical and autonomic activity in social phobics during anticipation of public speaking, Biological Psychiatry, 47, 85-95.

Deci, E.L. and Ryan, R.M. (2000) The 'what' and 'why' of goal pursuits: human needs and the self-determination of behavior, Psychological Inquiry, 11, 227-68.

Di Tella, R., MacCulloch, R.J., and Oswald. A.J. (2001) Preferences over inflation and unemployment: evidence from surveys of happiness, American Economic Review, 91, 335-41.

Diener, E., Suh, E.M., Lucas, R.E., and Smith, H.L. (1999) Subjective well-being: three decades of progress, Psychological Bulletin, 125, 276-303.

Easterlin, R.A. (1974) Does economic growth improve the human lot? Some empirical evidence, in P.A. David and M.W. Reder (eds) Nations and Households in Economic Growth: Essays in Honour of Moses Abramowitz, Academic Press, New York and London, 89-125.

Ehrhardt, J.J., Saris, W.E., and Veenhoven, R. (2000) Stability of life-satisfaction over time, Journal of Happiness Studies, 1, 177-205.

Falk, A. and Fischbacher, U. (2000) A theory of reciprocity, Working Paper No. 6, Institute for Empirical Research in Economics, University of Zurich.

Fehr, E. and Schmidt, K.M. (2003) Theories of fairness and reciprocity-evidence and economic applications, in M.D.watripont, L.P. Hansen, and S.J. Turnovsky (eds) Advances in Economics and Econometrics- $8^{\text {th }}$ World Congress, Econometric Society Monographs, Cambridge University Press, Cambridge, 208-57.

Fernández-Dols, J.-M. and Ruiz-Belda, M.-A. (1995) Are smiles a sign of happiness? Gold medal winners at the Olympic Games, Journal of Personality and Social Psychology, 69, 1113-9.

Fordyce, M.A. (1988) A review of research on happiness measures: a sixty second index of happiness and mental health, Social Indicators Research, 20, 355-81.

Freeman, R.B. (1978) Job satisfaction as an economic variable, American Economic Review, 68, 135-41.

Frey, B.S. (1994) Direct democracy: politico-economic lessons from Swiss experience, American Economic Review, 84, 338-48.

Frey, B.S., Benz, M., and Stutzer, A. (2004) Introducing procedural utility: not only what, but also how matters, Journal of Institutional and Theoretical Economics, 160, 000-000.

Frey, B.S. and Goette, L. (1998) Does the popular vote destroy civil rights?, American Journal of Political Science, 42, 1343-48. 
Frey, B.S. and Stutzer, A. (2000) Happiness, economy and institutions, Economic Journal, 110, 918-38.

Frey, B.S. and Stutzer, A. (2002a) What can economists learn from happiness research?, Journal of Economic Literature, 40, 402-35.

Frey, B.S. and Stutzer, A. (2002b) Happiness and Economics: how the Economy and Institutions Affect Human Well-Being, Princeton University Press, Princeton, NJ.

Gamble, B.S. (1997) Putting civil rights to a popular vote, American Journal of Political Science, 41, 245-69.

Hardin, R. (1982) Collective Action, John Hopkins University Press, Baltimore, MD.

Harsanyi, J.C. (1993) Normative validity and meaning of von Neumann-Morgenstern utilities, in K.B.nmore, A.K.rman, and P.T.ni (eds) Frontiers of Game Theory, MI.P.ess, Cambridge, MA, and London, 307-20.

Headey, B. and Wearing, A. (1991) Subjective well-being: a stocks and flows framework, in F.S.rack, M.A.gyle, and N.S.hwarz (eds) Subjective Well-Being: A.I.terdisciplinary Perspective, Pergamon Press, Oxford, 7-26.

Jones, P. and Hudson, J. (2000) Civic duty and expressive voting: is virtue its own reward?, Kyklos, 53, 3-16.

Juster, F., Stafford, T., and Stafford, F.P. (eds) (1985) Time, goods, and well-being, Institute for Social Research, The University of Michigan, Ann Arbor.

Kahneman, D., Diener, E., and Schwarz, N. (eds) (1999) Well-Being: The Foundation of Hedonic Psychology, Russell Sage Foundation, New York.

Kahneman, D., Knetsch, J.L., and Thaler, R.H. (1986) Fairness as a constraint on profit seeking: entitlements in the market, American Economic Review, 76, 728-41.

Kahneman, D., Wakker, P.P., and Sarin, R. (1997) Back to Bentham? Explorations of experienced utility, Quarterly Journal of Economics, 112, 375-405.

Kirchgässner, G., Feld, L., and Savioz, M.R. (1999) Die direkte Demokratie: Modern, erfolgreich, entwicklungs- und exportfähig, Helbing und Lichtenhahn, Basel, and Vahlen, Munich.

Koivumaa, H.H., Honkanen, R., Viinamaeki, H., Heikkilae, K., Kaprio, J., and Koskenvuo, M. (2001) Life satisfaction and suicide: a 20-year follow-up study, American Journal of Psychiatry, 158, 433-39.

Lane, R.E. (1988) Procedural goods in a democracy, Social Justice Research, 2, 177-92.

Lane, R.E. (2000) The Loss of Happiness in Market Economies, Yale University Press, New Haven, CT, and London.

Layard, R. (2005) Happiness-Lessons from a New Science, Penguin, New York

Le Menestrel, M. (2001) A process approach to the utility for gambling, Theory and Decision, 50, 249-62.

Leu, R.E., Burri, S., and Priester, T. (1997) Lebensqualität und Armut in der Schweiz, Haupt, Bern.

Lind, E.A. and Tyler, T.R. (1988) The Social Psychology of Procedural Justice, Plenum Press, New York.

Marmot, M.G. and Wilkinson, R.G. (eds) (1999) Social Determinants of Health, Oxford University Press, New York.

Marschak, J. (1950) Uncertain prospects, and measurable utility, Econometrica, 18, 111-41. 
Moulton, B.R. (1990) An illustration of a pitfall in estimating the effects of aggregate variables on micro units, Review of Economics and Statistics, 72, 334-38.

Mueller, D.C. (1989) Public Choice II, $2^{\text {nd }}$ edition, Cambridge University Press, Cambridge.

Oswald, A.J. (1997) Happiness and economic performance, Economic Journal, 107, 1815-31.

Pascal, B. (1670) Pensées, Port-Royal, Paris.

Putnam, R.D. (2000) Bowling Alone: The Collapse and Revival of American Community, Simon and Schuster, New York.

Rabin, M. (1993) Incorporating fairness into game theory and economics, American Economic Review, 83, 1281-302.

Rabin, M. (2002) A perspective on psychology and economics, European Economic Review, 46, 657-85.

Rosen, S. (1986) The theory of equalizing differences, in O.A.henfelter and R.L.yard (eds) Handbook of Labor Economics, Volume 1, North-Holland, Amsterdam, 641-92.

Sandvik, E., Diener, E. and Seidlitz, L. (1993) Subjective well-being: the convergence and stability of self-report and non-self-report measures, Journal of Personality, 61, 317-42.

Schuessler, A.A. (2000) Expressive voting, Rationality and Society, 12, 87-119.

Scitovsky, T. (1976) The Joyless Economy: an Inquiry into Human Satisfaction and Dissatisfaction, Oxford University Press, Oxford.

Sen, A.K. (1995) Rationality and social choice, American Economic Review, 85, 1-24.

Sen, A.K. (2002) Why health equity?, Health Economics, 11, 659-66.

Simon, H.A. (1976) From substantive to procedural rationality, in S.J. Latsis (ed.) Methods and Appraisal in Economics, Cambridge University Press, Cambridge, MA.

Simon, H.A. (1978) Rationality as a process and product of thought, American Economic Review, 68, 1-16.

Sproule-Jones, M. (1993) Governments at Work: Canadian Parliamentary Federalism and Its Public Policy Effects, University of Toronto Press, Toronto.

Stutzer, A. (1999) Demokratieindizes für die Kantone der Schweiz, Working Paper No. 23, Institute for Empirical Research in Economics, University of Zurich.

Swiss Federal Statistical Office (ed.) (1993-95) Statistisches Jahrbuch der Schweiz. Zurich, Neue Zürcher Zeitung.

Thibaut, J. and Walker, L. (1975) Procedural Justice: a Psychological Analysis, Erlbaum, Hillsdale, NJ.

Trechsel, A. and Serdült, U. (1999) Kaleidoskop Volksrechte: Die Institutionen der direkten Demokratie in den schweizerischen Kantonen 1970-1996, Genf, Basel, and Helbling \& Lichtenhahn, Munich.

Tyler, T.R., Boeckmann, R.J., Smith, H.J., and Huo, Y.J. (1997) Social Justice in a Diverse Society, Westview Press, Boulder, CO.

Veenhoven, R. (1993) Happiness in Nations: Subjective Appreciation of Life in 56 Nations 1946-1992, Erasmus University Press, Rotterdam.

Viscusi, W.K. (1993) The value of risks to life and health, Journal of Economic Literature, 31, 1912-46.

von Neumann, J. and Morgenstern, O. (1944) Theory of Games and Economic Behavior, Princeton University Press, Princeton, NJ. 
Zavoina, R. and McKelvey, W. (1975) A statistical model for the analysis of ordinal level dependent variables, Journal of Mathematical Sociology, 4, 103-20.

\section{Appendix}

Index for participation rights in Swiss cantons

Participation rights are measured here in terms of direct democratic participation possibilities. In Switzerland, at the national level, these rights apply equally to all citizens. However, these rights become very heterogeneous at the cantonal level. An index is constructed to measure the different barriers preventing citizens from entering the political process, apart from elections, in the year 1992. The index is based mainly on data collected in Trechsel and Serdült (1999) (for details see Stutzer, 1999).

The four main legal instruments directly influencing the political process in Swiss cantons are (i) the popular initiative to change the canton's constitution, (ii) the popular initiative to change the canton's law, (iii) the compulsory and optional referendum to prevent new law or changing law and (iv) the compulsory and optional referendum to prevent new state expenditure. Barriers are in terms of (i) the necessary number of signatures needed to launch an instrument (absolute and relative to the number of citizens with the right to vote), (ii) the legally allowed time span to collect the signatures and (iii) the level of new expenditure per head allowing a financial referendum. Compulsory referenda are treated like referenda with the lowest possible barrier. Each of these restrictions is evaluated on a six point scale: 'one' indicates a high barrier, 'six' a low one. From the resulting ratings, a non-weighted average is calculated for the composite index, which represents the measure of participation rights in Swiss cantons. The results are presented in Table A.1.

\section{Voting participation in national ballots across Swiss cantons}

The average participation rate is measured at the cantonal level. Actual participation in 45 national ballots on referenda and initiatives is taken into consideration. These ballots took place between February 19, 1992 and December 4, 1994. Table A.1 gives an overview of participation rates. The high participation rate in canton Schaffhausen is due to compulsory voting.

\section{Use of democratic participation rights across Swiss cantons}

The use of democratic participation instruments is measured by the total number of initiatives and referenda that were held in each canton in the years 1992 to 1994. 
Table A.1 Indicators of political participation across Swiss Cantons

\begin{tabular}{|c|c|c|c|}
\hline Canton & $\begin{array}{c}\text { Democratic } \\
\text { participation rights }\end{array}$ & $\begin{array}{l}\text { Voting participation } \\
\text { in national ballots }\end{array}$ & $\begin{array}{l}\text { Use of democratic } \\
\text { participation rights }\end{array}$ \\
\hline Aargau & 5.46 & 45.59 & 15 \\
\hline Appenzell i. Rh. & 5.25 & 47.99 & 19 \\
\hline Appenzell a. Rh. & 5.50 & 55.63 & 18 \\
\hline Bern & 3.50 & 49.30 & 21 \\
\hline Basel Landschaft & 5.69 & 51.70 & 18 \\
\hline Basel Stadt & 4.40 & 51.20 & 22 \\
\hline Fribourg & 2.42 & 42.22 & 6 \\
\hline Genve & 1.75 & 44.03 & 23 \\
\hline Glarus & 5.50 & 45.01 & 29 \\
\hline Graubünden & 4.75 & 40.21 & 20 \\
\hline Jura & 3.71 & 41.67 & 4 \\
\hline Luzern & 4.48 & 49.10 & 15 \\
\hline Neuchtel & 2.13 & 41.49 & 4 \\
\hline Nidwalden & 4.92 & 50.02 & 23 \\
\hline Obwalden & 5.58 & 45.20 & 20 \\
\hline St. Gallen & 3.40 & 49.11 & 6 \\
\hline Schaffhausen & 5.08 & 70.78 & 22 \\
\hline Solothurn & 5.42 & 55.97 & 32 \\
\hline Schwyz & 4.93 & 45.93 & 11 \\
\hline Thurgau & 4.04 & 49.48 & 8 \\
\hline Ticino & 2.10 & 46.40 & 5 \\
\hline Uri & 5.42 & 46.63 & 25 \\
\hline Vaud & 2.42 & 40.17 & 5 \\
\hline Valais & 3.42 & 45.56 & 14 \\
\hline Zug & 4.42 & 54.80 & 6 \\
\hline Zürich & 4.17 & 51.80 & 37 \\
\hline
\end{tabular}

Data sources: Année Politique Suisse (1993-95) and Swiss Federal Statistical Office (1993-95). 